\title{
GDGT distributions on the East Siberian Arctic Shelf: implications for organic carbon export, burial and degradation
}

\author{
R. B. Sparkes ${ }^{1}$, A. Doğrul Selver ${ }^{1}$, J. Bischoff ${ }^{2}$, H. M. Talbot ${ }^{2}$, Ö. Gustafsson ${ }^{3}$, I. P. Semiletov ${ }^{4,5,6}$, O. V. Dudarev ${ }^{4,6}$, \\ and B. E. van Dongen ${ }^{1}$ \\ ${ }^{1}$ School of Earth, Atmospheric and Environmental Sciences and Williamson Research Centre for \\ Molecular Environmental Science, University of Manchester, Manchester, UK \\ ${ }^{2}$ School of Civil Engineering and Geosciences, Newcastle University, Newcastle, UK \\ ${ }^{3}$ Department of Environmental Science and Analytical Chemistry (ACES) and the Bolin Centre for \\ Climate Research, Stockholm University, Stockholm, Sweden \\ ${ }^{4}$ Pacific Oceanological Institute, Far Eastern Branch of the Russian Academy of Sciences, Vladivostok, Russia \\ ${ }^{5}$ International Arctic Research Center, University of Alaska, Fairbanks, Alaska, USA \\ ${ }^{6}$ National Tomsk Research Polytechnic University, Tomsk, Russia
}

Correspondence to: R. B. Sparkes (robert.sparkes@manchester.ac.uk)

Received: 24 October 2014 - Published in Biogeosciences Discuss.: 12 January 2015

Revised: 22 May 2015 - Accepted: 27 May 2015 - Published: 18 June 2015

\begin{abstract}
Siberian permafrost contains a globally significant pool of organic carbon (OC) that is vulnerable to enhanced warming and subsequent release into the contemporary carbon cycle. OC release by both fluvial and coastal erosion has been reported in the region, but the behaviour of this material in the Arctic Ocean is insufficiently understood. The balance between OC deposition and degradation on the East Siberian Arctic Shelf (ESAS) influences the climate-carbon cycle feedback in this area. In this study we couple measurements of glycerol dialkyl glycerol tetraethers (GDGTs) with bulk geochemical observations to improve knowledge of the sources of OC to the ESAS, the behaviour of specific biomarkers on the shelf and the balance between delivery and removal of different carbon pools. Branched GDGT (brGDGT) concentrations were highest close to river mouths, yet low in "ice complex" permafrost deposits, supporting recent observations that brGDGTs are mostly delivered by fluvial erosion, and may be a tracer for this in complex sedimentary environments. BrGDGT concentrations and the branched and isoprenoidal tetraether (BIT) index reduced quickly offshore, demonstrating a rapid reduction in river influence. Stable carbon isotope ratios changed at a different rate to the BIT index, suggesting not only that $\mathrm{OC}$ on the shelf is sourced from fluvial erosion but also that erosion of coastal sediments delivers substantial quantities of $\mathrm{OC}$ to the
\end{abstract}

Arctic Ocean. A model of OC export from fluvial, coastal and marine sources is able to recreate the biomarker and bulk observations and provide estimates for the influence of fluvial and coastal OC across the whole shelf. The model shows that coastal erosion delivers $43 \%$ of the OC and $87 \%$ of the mineral sediment to the ESAS, but that rivers deliver $72 \%$ of brGDGTs, indicating that brGDGTs can be used as a proxy for river-derived sediment.

\section{Introduction}

Understanding natural processes and feedbacks within the global organic carbon cycle is necessary for a comprehensive understanding of Earth system dynamics and of continuing climate change. High latitudes account for nearly half of the global soil carbon stores (Tarnocai et al., 2009) and are a poorly understood region. Arctic permafrost carbon, in the form of tundra and taiga soils ( $\sim 1000 \mathrm{PgC})$, terrestrial ice complexes $(\sim 400 \mathrm{PgC})$ and submarine permafrost $\left(\sim 1400 \mathrm{PgC}\right.$ ) significantly outweighs the atmospheric $\mathrm{CO}_{2}$ pool ( 760 Pg C; Soloviev et al., 1987; Zimov et al., 2006; Tarnocai et al., 2009; Shakhova et al., 2010a, b; Semiletov et al., 2011), and is liable to become an active part of the carbon cycle in the region during the next century 
(Gustafsson et al., 2011). Observations and predictions of global climate change have shown that the polar regions are disproportionately affected by temperature increases (IPCC, 2013), leading to increased permafrost thawing, erosion of coastal permafrost and destabilisation of submarine permafrost (Semiletov, 1999a, b; Shakhova et al., 2009, 2014; Vonk et al., 2012).

Recent experiments have shown that long-term warming of permafrost reorganises the soil carbon stock, increasing decomposer activity in the mineral soil layer while also increasing the vegetation stock at the surface (Sistla et al., 2013). Changing pervasiveness of permafrost (i.e. from continuous to discontinuous coverage) introduces permeability, and allows groundwater flow to interact with deeply buried carbon (Gustafsson et al., 2011; Feng et al., 2013). This activation of deep carbon will lead not only to direct oxidation and $\mathrm{CO}_{2}$ release but also to increased erosion and offshore transport from the permafrost layer to the Arctic Ocean, enhanced by (already observed) increased river discharge (Savelieva et al., 2000; Semiletov et al., 2000, 2013; Peterson et al., 2002). Ultimately these processes will lead to increased input of terrestrial organic carbon (terrOC) to the Arctic Ocean, where it can interact with the biosphere. However, the fate of terrOC in the Arctic Ocean remains poorly understood.

Carbon stored within frozen soils and ice complexes is only released to the atmosphere if it becomes an active part of the carbon cycle. Inert transport from terrestrial to submarine storage (e.g. deposition as organic-rich sediment) has no net effect on global atmospheric carbon dioxide levels. However, any degradation during transport and deposition of carbon, previously sequestered for thousands of years, will release $\mathrm{CO}_{2}$ to the atmosphere (Arndt et al., 2013), causing a positive feedback effect on climate change. Some studies of global offshore terrOC burial have argued that there is extensive remineralisation once terrestrial material is delivered to the oceans (Hedges et al., 1997; Semiletov et al., 2007, 2012), whilst others have documented significant offshore terrOC burial, even over long transport distances (Galy et al., 2007; Kao et al., 2014). Therefore, understanding the fate of terrOC after it is transported to the Arctic marine environment is critical to quantify the carbon cycle in the polar region.

Recently, a number of studies have been published focusing on bulk and molecular level investigations of sediments exported from the Canadian and Siberian regions, attempting to better understand the behaviour of terrOC in lakes, rivers, estuaries and shelves (Cooke et al., 2008; Drenzek et al., 2007; Feng et al., 2013; Goñi et al., 2005; Guo et al., 2004; Gustafsson et al., 2011; Semiletov, 1999a, b; Semiletov et al., 2011; Tesi et al., 2014; van Dongen et al., 2008; Vonk et al., 2012). These studies have shown the presence of terrOC in marine settings offshore major Arctic rivers, and a transition from terrestrial- to marine-dominated geochemical signatures with increasing distance offshore. TerrOC in- put from coastal erosion is also a significant part of the Arctic carbon cycle (Semiletov et al., 2005, 2011, 2013; Vonk et al., 2012), and up to $44 \pm 10 \mathrm{Mt}$ of terrOC may be mobilised from permafrost coastal erosion each year. The distribution of stable carbon isotopes in sedimentary organic carbon $\left(\delta^{13} \mathrm{C}\right)$ in marine sediments was used to distinguish between the two biogeochemical provinces, western and eastern, in the East Siberian Arctic Shelf (ESAS; Semiletov et al., 2005).

Glycerol dialkyl glycerol tetraethers (GDGTs) have been identified as biomarker molecules for terrestrial and marine organic matter (Schouten et al., 2013; Sinninghe Damsté et al., 2002). Sourced from the cell membranes of bacteria and thaumarchaeota, they have been found in a range of terrestrial and marine sediments dating back millions of years (Schouten et al., 2013). Branched GDGTs (brGDGTs) contain 4-6 methyl branches along two $\mathrm{C}_{28}$ alkyl chains (Fig. S1 in the Supplement) and are produced by terrestrial bacteria in peats and soils (Weijers et al., 2006, 2007). They have also been found to be abundant in other terrestrial settings, including lakes and rivers (Blaga et al., 2009; De Jonge et al., 2014). Isoprenoidal GDGTs contain two $\mathrm{C}_{40}$ isoprenoid chains with varying number of cyclopentane rings. One of these, crenarchaeol (cren), which is dominantly produced by marine thaumarchaeota, contains a cyclohexane unit in addition to four cyclopentane rings (Fig. S1). The ratio of brGDGTs to cren forms the basis of the branched and isoprenoidal tetraether (BIT) index (Hopmans et al., 2004), a proxy for tracing terrestrial material in marine sediments. The BIT index has been used to infer terrestrial to marine transitions along river-ocean transects in (sub)-Arctic and non-Arctic regions (Kim et al., 2006; Zhu et al., 2011; Doğrul Selver et al., 2012). Recent studies have inferred that a portion of the brGDGTs in the Arctic region may be produced within rivers, rather than being harvested entirely from soil erosion during the freshet, and that brGDGTs and BIT can be used to trace fluvial erosion offshore (De Jonge et al., 2014; Kim et al., 2014; Peterse et al., 2014). Therefore the relationship between river outflows and the Arctic Shelf is worth investigation to understand the delivery of organic matter to the Arctic Ocean and its eventual fate. Differences in amount, distribution and eventual fate between coastal and fluvial OC delivery can have severe implications for climate change and feedbacks.

This study aims to use a combination of GDGT biomarkers and stable carbon isotope proxies measured on a series of surface sediments from across the entire ESAS, including transects of the major Russian Arctic rivers in this area (Lena, Indigirka and Kolyma) and areas of coastal erosion, to investigate the transport and fate of terrestrial organic carbon in a region which has experienced little scientific investigation but is likely to experience extreme climate change in the next century. Combining these proxies allows us to (i) differentiate between the different fractions of terrOC (coastal ice complex OC and river-transported terrOC) which will likely have different degradation potentials and (ii) observe whether 
bulk terrOC and a specific fraction of the terrOC behave similarly.

\section{Methods}

\subsection{Study area and sample collection}

Samples used in present study were collected from across the ESAS (130 to $175^{\circ} \mathrm{E}$; Fig. 1). This area, including the Laptev and East Siberian seas, spans the outflows of the Lena, Yana, Indigirka and Kolyma rivers, with a combined drainage area of $3.7 \mathrm{~km} \times 106 \mathrm{~km}$ and a discharge of $7.3 \times 10^{11} \mathrm{~m}^{3} \mathrm{yr}^{-1}$ (Gordeev, 2006; see Table 1). Annual organic carbon export into the Laptev and East Siberian seas is estimated as 10.22 $\mathrm{MtC} \mathrm{yr}^{-1}$ (Rachold et al., 2002). The Lena River is the largest of the rivers in this region and forms a substantial delta reaching into the Arctic Ocean, whilst the other three form smaller, more tide-dominated deltas. Due to a reduction in protective sea ice, potentially enhanced by climate warming, this region is also the site of severe coastal erosion of terrestrial ice complexes (ice-, dust- and carbon-rich deposits also known as "yedoma"; Schirrmeister et al., 2011), which has been estimated to deliver $44 \pm 10 \mathrm{MtC} \mathrm{yr}^{-1}$ to the East Siberian Shelf (Vonk et al., 2012). Ice complexes are a relatively organic-rich mixture of permafrost and sediment of Pleistocene age that exist in metres-thick layers underlying large amounts of eastern Siberia (Schirrmeister et al., 2011; Peterse et al., 2014). Focusing on the drainage basins, eastern Siberia is a region with predominantly continuous permafrost, with the subsoil remaining permanently below $0{ }^{\circ} \mathrm{C}$ and being impermeable to water flow (van Everdingen, 1998). Eurasian permafrost soils contain $120000 \mathrm{MtC}$, of which $74 \%$ is stored within continuous permafrost (Tarnocai et al., 2009), with the majority of the continuous permafrost existing within the East Siberian region. At the surface there are many small lakes and there is seasonal ice cover for up to 9 months per year, with the majority of the sediment and water discharge during the early summer (Gordeev, 2006). Offshore there is a narrow channel between the coastline at $\sim 140^{\circ} \mathrm{E}$ and the New Siberian Islands, known as the Dmitry Laptev Strait (DLS), splitting the ESAS up into two distinct areas - the Laptev Sea and East Siberian Sea (Fig. 1). The New Siberian Islands themselves are remnants of the Great Arctic Plain, which once covered $1.6 \mathrm{~km} \times 106 \mathrm{~km}$ between the modern coastline and the shelf edge, and was inundated during the early-middle Holocene, and now exists as substantial subsea permafrost (Kienast et al., 2005; De Jonge et al., 2014). Samples in this study have been grouped based on their location on the ESAS. Mostly, samples have been grouped longitudinally, into the Buor-Khaya Bay and associated region offshore the Lena River, the DLS, the region offshore the Indigirka River and the region offshore the Kolyma River. The Indigirka and Kolyma offshore regions are generally equivalent to the western and eastern East Siberian Sea

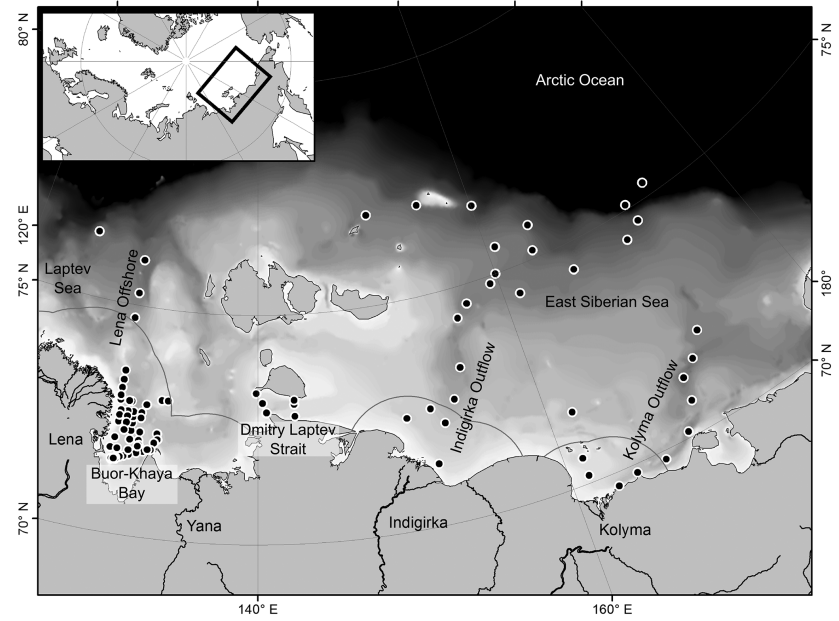

Figure 1. Map of the East Siberian Arctic Shelf (ESAS) showing the location of the ISSS-08 sampling stations. Key regions referred to in the text are highlighted. The lower courses and outflows of four great Russian Arctic rivers are labelled.

regions, respectively, as identified by Semiletov et al. (2005). The ESAS samples have also been classified latitudinally, into the nearshore ESAS ( $<150 \mathrm{~km}$ from river outflows) and offshore ESAS ( $>150 \mathrm{~km}$ from river outflows). In total, 92 sediment samples were collected in September 2008 during the International Siberian Shelf Study expedition (ISSS08; Semiletov and Gustafsson, 2009; Fig. 1), along with six samples from terrestrial ice complexes. Briefly, sediment cores and surface sediments were collected with a dual gravity corer (GEMAX) and a van Veen grab sampler. The sediment cores were sliced into $1 \mathrm{~cm}$ sections and transferred to pre-cleaned polyethylene containers with stainless steel spatulas. Similarly, surface sections of the grab samples were obtained with stainless steel spatulas, transferred to pre-cleaned polyethylene containers. Terrestrial ice complex samples were collected from river bank erosion profiles near to the mouths of the Indigirka and Kolyma rivers (Tesi et al., 2014). All sediments were kept frozen until analysis, in order to mitigate microbial degradation, and subsequently preserved by freeze or oven drying $\left(50^{\circ} \mathrm{C}\right)$.

\subsubsection{Extraction and instrumental analysis}

Freeze-dried sediment samples were extracted using a modified Bligh-Dyer method as described by Tierney et al. (2012). Approximately $5 \mathrm{~g}$ (dry weight) of sediment was ultrasonically extracted (at $40^{\circ} \mathrm{C}$ for $10 \mathrm{~min}$ ) using $19 \mathrm{~mL}$ of a mixture of methanol: dichloromethane:aqueous phase (MeOH:DCM:aqueous phase, 2:1:0.8 v/v/v), with the aqueous phase consisting of $0.05 \mathrm{M}$ phosphate buffer at $\mathrm{pH}$ 7.4. Samples were centrifuged for $5 \mathrm{~min}$ at $2500 \mathrm{rpm}$, supernatants were collected and the extractions were repeated two additional times using the same solvent mixture. The DCM fractions were recovered by addition of $5 \mathrm{~mL}$ each 
Table 1. Physical properties of major rivers draining East Siberia.

\begin{tabular}{lcccc}
\hline River & $\begin{array}{c}\text { Basin area* } \\
10^{3} \mathrm{~km}^{2}\end{array}$ & $\begin{array}{c}\text { Water discharge* } \\
\mathrm{km}^{3} \mathrm{yr}^{-1}\end{array}$ & $\begin{array}{c}\text { Sediment discharge* } \\
10^{6} \mathrm{tyr}^{-1}\end{array}$ & $\begin{array}{c}\text { Continuous permafrost*,** } \\
\% \text { of basin area }\end{array}$ \\
\hline Lena & 2448 & 523 & 20.7 & 71 \\
Yana & 225 & 32 & 4.0 & 100 \\
Indigirka & 360 & 54 & 11.1 & 100 \\
Kolyma & 647 & 122 & 10.1 & 99 \\
\hline
\end{tabular}

${ }^{*}$ Gordeev (2006). ${ }^{* *}$ Kotlyakov and Khromova (2002).

of phosphate buffer and DCM to the supernatants. Combined DCM fractions were rotary-evaporated to near dryness, transferred to vials using a solution of DCM : $\mathrm{MeOH}$ $(2: 1 \mathrm{v} / \mathrm{v})$ and evaporated to dryness under a stream of $\mathrm{N}_{2}$ to obtain the total lipid extract (TLE). Core lipid (CL) fractions were isolated using silica column chromatography with $4 \mathrm{~mL}$ of hexane : ethyl acetate $(1: 1, v / v)$ as the eluent. A total of $0.2 \mu \mathrm{g}$ of a synthetic $\mathrm{C}_{46}$ GDGT standard was added to the CLs, which were dried under $\mathrm{N}_{2}$, re-dissolved in hexane : isopropanol $(99: 1 \mathrm{v} / \mathrm{v})$ and filtered through a $0.45 \mu \mathrm{m}$ PTFE filter. GDGTs analysis was carried out on the CLs via high-performance liquid chromatography-atmospheric pressure chemical ionisation mass spectrometry (HPLC-APCIMS) using the method reported by Hopmans et al. (2004). Analyses were performed using an Agilent 1200 HPLC coupled to an Agilent 6130 quadrupole MS instrument equipped with a multimode source operated in APCI positive ion mode using a similar instrumental setup as described by McClymont et al. (2012). The GDGTs were analysed using normal phase LC-MS with a Grace Prevail Cyano HPLC column $(3 \mu \mathrm{m}, 150 \mathrm{~mm} \times 2.1 \mathrm{~mm}$ i.d.) and a guard column of the same material. Separation was achieved at $30^{\circ} \mathrm{C}$ with a flow rate of $0.2 \mathrm{~mL} \mathrm{~min}^{-1}$ and the following gradient profile: $1 \%$ isopropanol (IPA) in hexane $(0-5 \mathrm{~min}), 1.8 \%$ IPA in hexane (at $25 \mathrm{~min}$ ) and $10 \%$ IPA in hexane (at $30 \mathrm{~min}$, held for $10 \mathrm{~min}$ ). Conditions for APCI were as follows: nebuliser pressure $20 \mathrm{psig}$, vaporiser temperature $250^{\circ} \mathrm{C}$, drying gas $\left(\mathrm{N}_{2}\right)$ flow $6 \mathrm{~L} \mathrm{~min}^{-1}$ and temperature $200^{\circ} \mathrm{C}$, capillary voltage $2 \mathrm{kV}$ and corona $5 \mu \mathrm{A}$. In order to increase sensitivity/reproducibility, ion scanning was performed in single ion monitoring (SIM) mode using GDGT $[\mathrm{M}+\mathrm{H}]^{+}$ions. Peak areas were measured, and concentrations of individual GDGTs were calculated using a combination of the peak area of the $\mathrm{C}_{46}$ synthetic standard and a series of response factors for each GDGT calculated based on the peak areas of multiple runs of standard samples with known concentrations of brGDGTs, cren and $\mathrm{C}_{46}$ standard. This corrects for the differences in ionisation between compounds, as shown by Schouten et al. (2013). Previous studies have shown that a proportion of the CLs may carry over from the column (Weijers et al., 2011) and a correction may be applied for this. However, this carry-over was insignificant, up to $2 \%$ of the CLs. In the present study, a correction factor was not applied for this issue, but it may be that the GDGT concentrations are up to $2 \%$ higher than is reported. BIT index values were calculated according to the corrected peak areas of the branched GDGTs and cren, following the method of Hopmans et al. (2004):

$\mathrm{BIT}=\frac{(\text { brGDGT I }+\mathrm{II}+\mathrm{III})}{(\text { brGDGT I }+\mathrm{II}+\mathrm{III}+\text { cren })}$.

The BIT index returns a value of approximately 1 in a purely terrestrial setting, and 0 in a marine setting. Cren can be found in some terrestrial settings, including soils and rivers (Weijers et al., 2006; Zell et al., 2013; De Jonge et al., 2014), leading to BIT measurements of slightly less than 1 .

\section{Results and discussion}

Sedimentary organic carbon (OC) concentrations (from Vonk et al., 2012) ranged from 0.68 to $2.25 \mathrm{wt}$ \% $\mathrm{C}$. OC concentration was highest in the Buor-Khaya Bay, and relatively uniform across the rest of the ESAS. $0-100 \mathrm{~km}$ from the river outflows, TOC averaged $1.81 \pm 0.10 \%, 100-800 \mathrm{~km}$ away it averaged $0.88 \pm 0.06 \%$ (Table 2).

\subsection{GDGT concentrations}

Liquid chromatography mass spectrometry analysis showed a wide range of concentrations for both brGDGTs and cren throughout the sediments (Fig. 2a and b). BrGDGT concentrations ranged from below detection limit (BDL) to $180 \mu \mathrm{gg}_{\mathrm{OC}}^{-1}\left(2046 \mathrm{ngg}_{\text {sed }}^{-1}\right)$, with the highest concentrations observed close to river mouths - especially the Lena River, which is the largest of the rivers in the study area and exports the largest amount of sediment $\left(20 \times 10^{6} \mathrm{tyr}^{-1}\right.$; Gordeev, 2006). Within the Buor-Khaya Bay, brGDGT concentrations were highest in the south-western corner of the bay, beside the major outflows of the Lena Delta, and reduced with distance across the bay. Nearshore ESAS samples, less than $150 \mathrm{~km}$ from the river mouths, averaged $30 \mu \mathrm{g} \mathrm{g}_{\mathrm{OC}}^{-1}$ $\left(203 \mathrm{ng} \mathrm{g}_{\text {sed }}^{-1}\right.$ ), whilst samples $>150 \mathrm{~km}$ offshore averaged $14 \mu \mathrm{gg}_{\mathrm{OC}}^{-1}\left(136 \mathrm{ng} \mathrm{g}_{\text {sed }}^{-1}\right.$; Fig. S2a).

When plotted against the distance from river outflows, the offshore trend in brGDGT concentrations showed a rapid decrease in concentration (Fig. 3a). Samples within $100 \mathrm{~km}$ 
Table 2. Summed brGDGTs, crenarchaeol concentrations, BIT, $\delta^{13} \mathrm{C}$ and TOC values on the East Siberian Arctic Shelf, grouped by distance from river mouths.

\begin{tabular}{|c|c|c|c|c|c|c|}
\hline $\begin{array}{l}\text { Distance from } \\
\text { rivers* }{ }^{*} \mathrm{~km}\end{array}$ & $n$ & $\begin{array}{c}\Sigma \text { brGDGTs } \\
\text { ng g }_{\text {sed }}-1\end{array}$ & $\begin{array}{l}\text { Crenarchaeol } \\
\operatorname{ngg}_{\text {sed }}-1\end{array}$ & BIT & $\begin{array}{r}\delta^{13} \mathrm{C}^{* *} \\
\% \text { o }\end{array}$ & $\begin{array}{r}\text { TOC } \\
\%\end{array}$ \\
\hline $0-100$ & 46 & 668 & 475 & 0.58 & -26.05 & 1.81 \\
\hline $100-200$ & 13 & 227 & 781 & 0.32 & -25.95 & 0.79 \\
\hline $200-300$ & 12 & 306 & 815 & 0.37 & -26.55 & 0.96 \\
\hline $300-400$ & 5 & 129 & 3595 & 0.04 & -24.60 & 0.94 \\
\hline $400-500$ & 5 & 136 & 2611 & 0.05 & -24.60 & 0.91 \\
\hline $500-600$ & 3 & 84 & 2164 & 0.04 & -23.70 & 0.78 \\
\hline $600-700$ & 6 & 62 & 1984 & 0.03 & -22.88 & 0.83 \\
\hline $700-800$ & 2 & 13 & 971 & 0.01 & -21.35 & 0.97 \\
\hline
\end{tabular}

* This distance was measured radially in kilometres from a series of outflows shown in the NOAA GSHGG river data set. ${ }^{* *}$ As reported in Vonk et al. (2012).

of the river mouths had an average brGDGT concentration of $38 \pm 3 \mu \mathrm{g} \mathrm{g}_{\mathrm{OC}}^{-1}\left(668 \pm 65 \mathrm{ng} \mathrm{g}_{\text {sed }}^{-1}\right)$, by $300-400 \mathrm{~km}$ offshore the concentration was only $15 \pm 4 \mu \mathrm{gg}_{\mathrm{OC}}^{-1}\left(129 \pm 31 \mathrm{ng} \mathrm{g}_{\text {sed }}^{-1}\right)$, and $700-800 \mathrm{~km}$ offshore the average was $1.3 \pm 1.0 \mu \mathrm{gg}_{\mathrm{OC}}^{-1}$ $\left(13 \pm 11 \mathrm{ng} \mathrm{g}_{\text {sed }}^{-1}\right.$; Tables 1 and S1 in the Supplement). Tesi et al. (2014) found similarly rapid decreases in the concentration of lignin phenols and cutin acids along the same sample transect. The brGDGT concentration per gram of sediment had a power-law reduction $\left(y=a x^{b}\right)$ with an exponent of $b=-0.92$ and an $r^{2}$ value of 0.52 . In a similar analysis, Zhu et al. (2013) found power-law relationships between water depth and concentration for GDGTs and other biomarkers in the East China Sea. Given that the bathymetry of the ESAS is very flat, the equivalent in this case is to plot against distance offshore. Our results show that rapid offshore decreases in brGDGT concentrations are not an isolated observation. This sharp decrease in brGDGT concentration could be due to either a rapid sedimentation of brGDGT-rich material close to the shoreline, or the remineralisation of GDGT compounds during transport to the more distal locations.

Cren ranged from 2.05 to $656 \mu \mathrm{g} \mathrm{g}-1$ ( 24 to $\left.8116 \mathrm{ng} \mathrm{g}_{\text {sed }}^{-1}\right)$ with the lowest values in the coastal areas and the highest cren concentration at site YS-40, $391 \mathrm{~km}$ offshore from the Kolyma River outflow (Figs. 3b and S2b, location details in Table S1). Other regions of high cren concentration were the area east of longitude $160^{\circ} \mathrm{E}$, and north of the Lena Delta. The increase in cren east of $160^{\circ} \mathrm{E}$ corresponds to the "eastern ESS" region defined by Semiletov et al. (2005), and suggests a region more affected by marine processes than the remainder of the ESAS. The most distal sediments showed a reduction in cren concentration, with mean values of $\sim 197 \mu \mathrm{gg}_{\text {OC }}^{-1}\left(970 \mathrm{ng} \mathrm{g}_{\text {sed }}^{-1}\right)$ among the samples collected at the edge of the shelf. Cren trends offshore were also non-linear, with the concentration peaking $300-400 \mathrm{~km}$ from the river mouths (average concentration $\left.358 \pm 65 \mu \mathrm{gg}_{\mathrm{OC}}^{-1}, 3600 \pm 1200 \mathrm{ng} \mathrm{g}_{\text {sed }}^{-1}\right)$. Nearshore and far offshore the average values were much lower $(0-100 \mathrm{~km}$ :
$38 \pm 8 \mu \mathrm{g} \mathrm{g}_{\mathrm{OC}}^{-1}, 480 \pm 50 \mathrm{ng} \mathrm{g}_{\text {sed }}^{-1} ; 700-800 \mathrm{~km}: 95 \pm 73 \mu \mathrm{g} \mathrm{g}_{\mathrm{OC}}^{-1}$ $970 \pm 774 \mathrm{ng} \mathrm{g}_{\text {sed }}^{-1}-$ see Table 2). A similar pattern in marine production has been observed in other transects of the Arctic coast, such as offshore northern Alaska (Belicka and Harvey, 2009) and may be due to a combination of (local) factors. Close to the shore the presence of fast ice for most of the year could reduce primary productivity, whilst far offshore the ice cap may have the same effect (Sakshaug and Slagstad, 1992; Cremer, 1999; Xiao et al., 2013) Measurements in the Laptev Sea of dinosterol and brassicasterol, biomarkers for open-water phytoplankton (Xiao et al., 2013), showed a similar pattern, although the maximum concentrations of these biomarkers were $76-79^{\circ} \mathrm{N}$, further offshore than the cren peak. The authors suggested that maximum primary productivity is in the open water and polynyas between the terrestrially bound fast ice and the permanent open-ocean ice sheet. Onshore, in ice complex samples, total brGDGT concentrations were $129 \mathrm{ng} \mathrm{g}_{\text {sed }}^{-1}$, and cren concentrations $124 \mathrm{ng} \mathrm{g}_{\text {sed }}^{-1}$. These values are very low compared to the ESAS samples, especially the brGDGT concentration compared to samples collected in the Buor-Khaya Bay or close to river outflows (Fig. S2). Peterse et al. (2014) report comparable results: brGDGT concentrations of $77 \pm 50 \mathrm{ng} \mathrm{g}_{\text {sed }}^{-1}$, cren concentrations of $16 \pm 11 \mathrm{ng} \mathrm{g}_{\text {sed }}^{-1}$ and BIT values of $0.83 \pm 0.02$. These results both suggest that erosion of ice complex is unlikely to be the main source of brGDGTs or cren to the ESAS.

\subsection{Spatial GDGT distributions and BIT}

BrGDGTs and cren had very different concentration relationships across the shelf (Figs. 2a and $\mathrm{b}$ and 3). Plotting cren concentration against brGDGT concentration shows that all nearshore samples are grouped together, having low cren concentrations, whilst all offshore ESAS samples are in a distinct group with high cren and low brGDGT concentrations (Fig. 4). The existence of these two groups is visible in the BIT index - Fig. 2c shows a map of BIT index across the ESAS. BIT was highest in the Buor-Khaya Bay, especially 

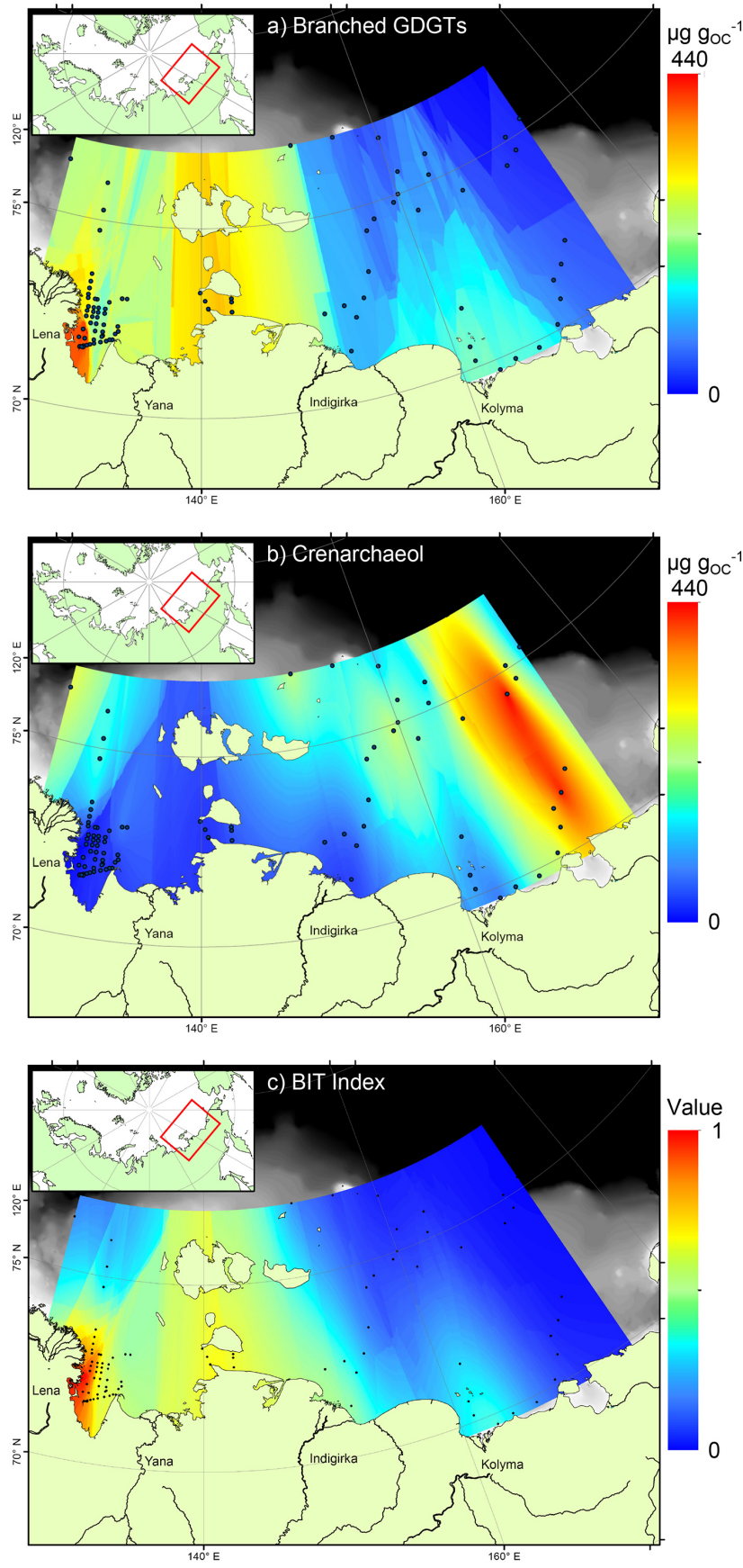

Figure 2. Maps of (a) summed brGDGTs and (b) crenarchaeol concentrations, and (c) the BIT index on the ESAS. Maps were interpolated using a kriging algorithm, and the locations of ISSS-08 stations are shown with black dots.

close to the Lena River outflows (Fig. 2c). The stations closest to the Lena, TB-30, 40, 46, 47 and 48, had an average BIT value of 0.91 , compared to the bay as a whole, which averaged 0.58 (Table S1). Given a terrestrial BIT value of 1 (Hopmans et al., 2004), this strongly suggests a terrestrial source of the sediment deposited here, and a fluvial source to the
brGDGTs (De Jonge et al., 2014; Peterse et al., 2014), and is similar to patterns seen in other locations (Doğrul Selver et al., 2012; Zhu et al., 2013). The BIT index values averaged $0.58 \pm 0.03$ in the $100 \mathrm{~km}$ closest to all river outflows, dropping to $0.04 \pm 0.01$ when $300-400 \mathrm{~km}$ offshore. A strong relationship is observed when the BIT index is plotted against the distance from the outflows of major rivers (Fig. 5a). The BIT index decreased rapidly in the first $150 \mathrm{~km}$ offshore before reducing more slowly across the ESAS. This was seen for the Lena, Indigirka and Kolyma offshore regions, as well as the open shelf. Ho et al. (2014) report BIT values from the Laptev Sea that show similar trends, reducing quickly offshore. However, their results are not quantitatively comparable to this study since a correction factor (Schouten et al., 2013) was not applied during analysis. In contrast, the rapidly decreasing pattern was not seen in the DLS. Although the DLS is influenced by freshwater from the Lena River (Semiletov et al., 2005, 2011; Shakhova and Semiletov, 2007), it is a long distance from any river outflows and yet has a relatively high BIT value of $0.55 \pm 0.06$. Excluding data from the DLS, which will be discussed separately, there is a strong power-law correlation $\left(y=a x^{b}\right)$ between BIT and distance from rivers, with a value for exponent $b$ of -1.209 (Fig. $5 \mathrm{a},\left(r^{2}\right)=0.85 p \leq 0.00001$ ). To test this further, the BIT indices of offshore regions from the Lena (Laptev Sea), Indigirka (East Siberian Sea $<160^{\circ}$ E) and Kolyma (East Siberian Sea $>160^{\circ}$ E) rivers were plotted against distance from river outflows in log-log space (Fig. 5b). The gradients of the associated trend lines correspond to the exponential value $(b)$ of each transect. The values for the Lena $(b=0.903)$ and Indigirka $(b=0.953)$ are comparable, but the values for the Kolyma region seem substantially higher $(b=1.302)$, denoting a more rapid shift to a marine-dominated system. The offshore Kolyma region showed linear rather than power-law reductions in high/lowmolecular-weight $n$-alkanes (Vonk et al., 2010). Measurements of lignin phenols from the same region showed rapid offshore decline but did not show the spatial variance in reduction rates (Tesi et al., 2014). The sediments from the most distal part of the Kolyma offshore region appear to have abnormally low BIT values compared to the nearshore sediments. These sediments are in a region that can potentially be influenced by inflow of Pacific Ocean water from the Bering Strait (Semiletov et al., 2005), where incoming nutrients could stimulate primary productivity, as indicated by the extremely high cren values. The nearshore section of the Kolyma region gives a value $(b=0.945)$ comparable to the other two regions. The similarity of each region studied, each showing a power-law reduction in BIT with distance despite a spatial separation of hundreds of kilometres, suggests that the processes affecting brGDGT degradation and cren production are similar across the whole ESAS. The absolute amounts of brGDGTs and cren differ for each river (Figs. 2a and $b$ and S3a), and each region has a different BIT value for 

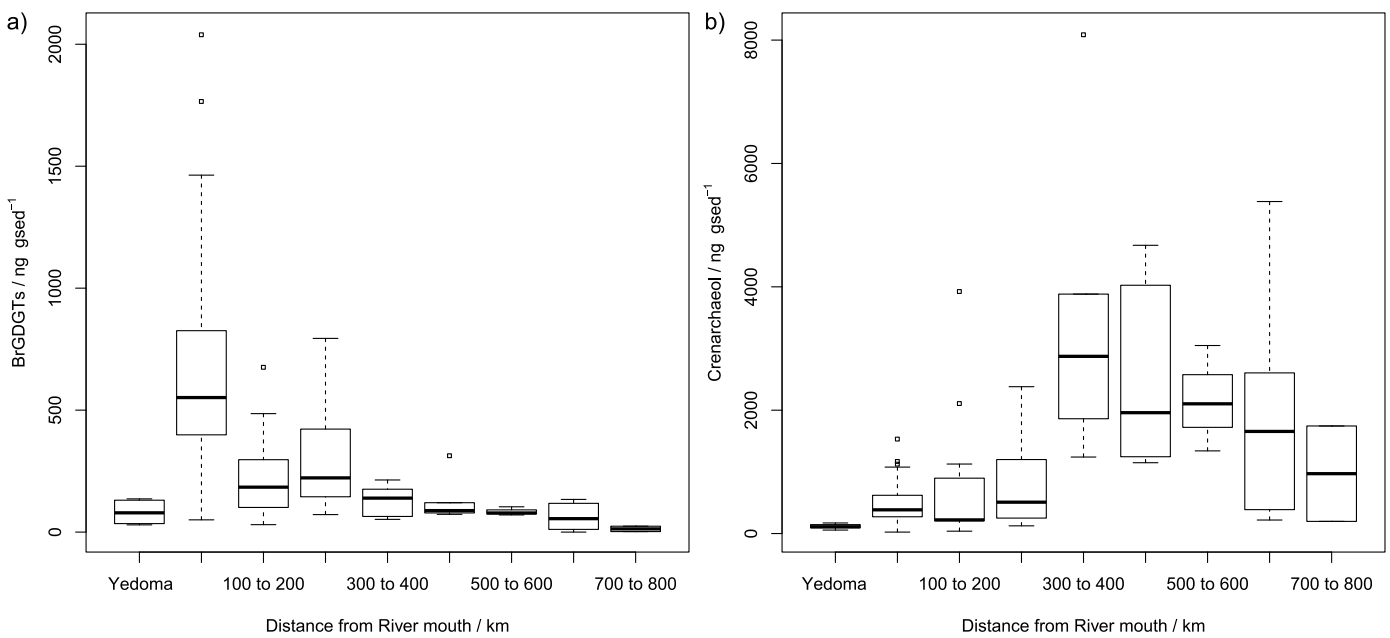

Figure 3. Box plots summarising the concentrations of (a) brGDGTs and (b) crenarchaeol on the ESAS, grouped by distance from river mouths. Concentrations in ice complex samples are also shown. Thick lines show the median values, boxes the 25 th and 75 th percentiles, whiskers the maximum and minimum values within 1.5 times the interquartile range, and square symbols the outliers beyond this threshold.

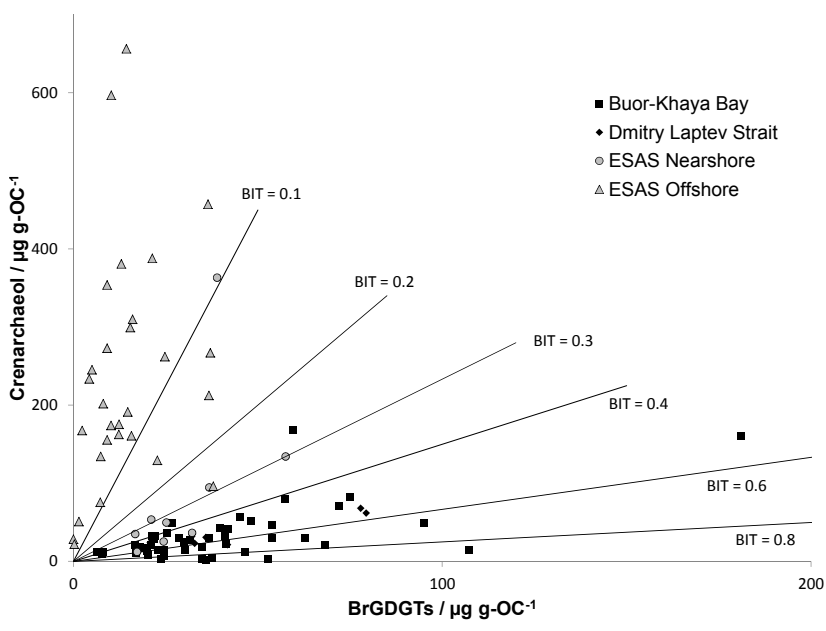

Figure 4. Plot of crenarchaeol vs. brGDGT concentration. Nearshore samples from the Buor-Khaya Bay, DLS and nearshore ( $<150 \mathrm{~km}$ from river mouths) ESAS have low crenarchaol concentrations. Offshore ESAS samples ( $>150 \mathrm{~km}$ from river mouths) have high crenarchaeol concentrations. Labelled contours show the BIT index values.

a given distance offshore (Figs. $2 c$ and $5 b$ ), yet the rate of reduction offshore is remarkably comparable.

The DLS is unusual for its relatively high BIT index compared to its location, over $200 \mathrm{~km}$ from a major river outflow. This area is a region of high coastal erosion and the outflow of the Lena and Yana rivers is channelled through the DLS - the eastward branch of the Lena River outflow determines the fresh water balance and thermal regime of the strait, but particulate matter is dominated by coastal erosion (Semiletov et al., 2005; Shakhova and Semiletov, 2007). Given that the BIT index appears to decrease based on the distance from fluvial outflows (Fig. 5a), and therefore brGDGTs are likely delivered by rivers, one possibility could be that either the Lena River outflow or minor rivers discharging into this area are providing the brGDGTs, giving an enhanced BIT index. However, Figs. 2a and S2a show that brGDGT concentrations in this area are not especially high, and that there is a decreasing trend going eastward from the Lena Delta. The cren concentrations in this region are very low (Figs. $2 \mathrm{~b}$ and $\mathrm{S} 2 \mathrm{~b}$ ), and it is this that is driving the high BIT index in the area. The DLS may be poor in cren due to sea-ice cover reducing primary productivity. Sakshaug and Slagstad (1992) found that later melting times for sea-ice cover reduced seasonal primary productivity. Retreating ice causes a plankton bloom and initiates the growing season in that area. Xiao et al. (2013) report that the boundary between sea ice and continentally anchored fast ice forms open-water polynyas roughly equivalent to the peak cren regions, and the fast ice then retreats throughout the summer. Summer sea-ice concentrations are higher in the DLS than other coastal areas, which could lead to the extremely low cren concentrations. Future changes in ice cover will likely lead to increased marine productivity in this region, and may therefore reduce BIT values (Arrigo et al., 2008). Alternatively, because the ESAS is characterised by very low transparency, which limits euphotic layer thickness (Semiletov et al., 2007, 2013; Heim et al., 2014), increasing river discharge will further decrease transparency, affecting marine productivity, and may therefore increase BIT values in the future.

\subsection{Stable carbon isotopes and BIT}

Stable carbon isotope values $\left(\delta^{13} \mathrm{C}\right)$ can be used as a bulk proxy for marine vs. terrestrial influence on sediment organic carbon composition. Marine productivity produces material 


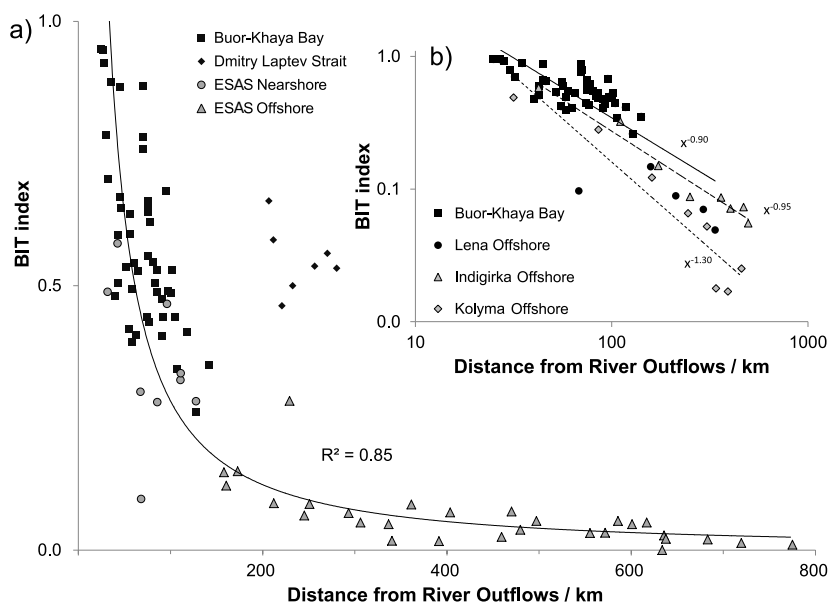

Figure 5. Plot of BIT index vs. linear distance from river mouths. (a) Plotted in linear space, showing the strong power-law relationship between the BIT and distance (with the exception of the DLS samples) and (b) plotted in log-log space. Outflows from the Lena, Indigirka and Kolyma rivers are comparable, with power-law coefficients labelled.

with a more positive $\delta^{13} \mathrm{C}$ value compared to terrOC. $\delta^{13} \mathrm{C}$ values of the surface sediments, sourced from Vonk et al. (2012) were analysed in combination with the GDGT results. $\delta^{13} \mathrm{C}$ ranged from -21.2 to $-27.5 \%$, with most depleted values in the DLS, and most enriched values on the distal shelf, again showing a transition from terrestrial to marine dominance offshore. The Buor-Khaya Bay samples were also depleted, although less so than the DLS, and showed no significant variation across the Buor-Khaya Bay, in contrast to the BIT values (Fig. 6). There was a linear relationship between $\delta^{13} \mathrm{C}$ and distance offshore. For samples from the Indigirka and Kolyma regions, and across the offshore ESAS, the correlation was very strong $\left(r^{2}=0.90\right)$. This is in contrast to the BIT index, which had a strongly non-linear relationship. The relationship between $\delta^{13} \mathrm{C}$ and BIT was therefore also non-linear, albeit with a strong correlation between the two (Fig. 6). This was observed in the Kolyma River transect and attributed to the higher degradation rate of brGDGTs compared to other fractions of terrOC and/or a significantly higher cren addition compared to addition of other marine compounds (Doğrul Selver et al., 2015). Here, for the first time, decoupled offshore trends in BIT and $\delta^{13} \mathrm{C}$ were observed.

In the Buor-Khaya Bay, DLS and within $150 \mathrm{~km}$ of the coastline, the $\delta^{13} \mathrm{C}$ value was between -25 and $-28 \%$ and showed no significant trend, whilst the BIT value dropped from 1 to 0.28 in an offshore direction. Greater than $150 \mathrm{~km}$ offshore, the BIT value decreases from 0.22 to 0 , and the $\delta^{13} \mathrm{C}$ value enriches from -26 to $-21 \%$, creating an inflection at $\delta^{13} \mathrm{C}=-26 \%$ and $\mathrm{BIT}=0.25$. Considering that both $\delta^{13} \mathrm{C}$ and BIT are used as proxies to quantify the proportion of terrestrial and marine material in offshore sediments (Be-

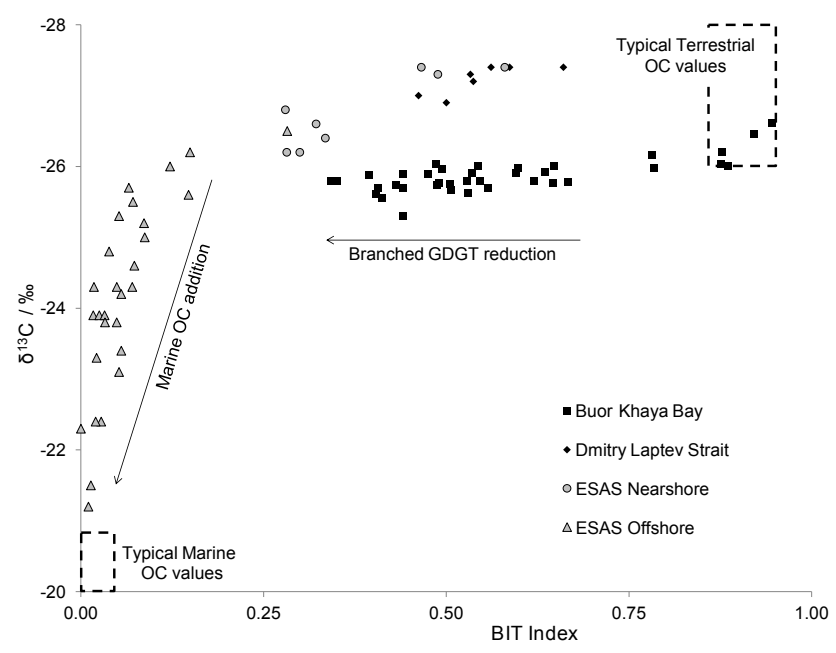

Figure 6. Plot of $\delta^{13} \mathrm{C}$ vs. BIT index. Typical values for terrestrial and marine endmember samples are shown (Hopmans et al., 2004; Vonk et al., 2012). Note the non-linearity of the relationship; the BIT index drops significantly before a shift in isotope ratio to more marine values.

licka and Harvey, 2009; Doğrul Selver et al., 2012, 2015; Karlsson et al., 2011; Semiletov et al., 2005; Smith et al., 2012; Zhu et al., 2011), this apparent disagreement, which has not been seen in studies elsewhere, may suggest that on the ESAS they are measuring different aspects of the terrestrial sediment export. Vonk et al. (2012) showed that the ice complexes that dominate the East Siberian coastline are at least as rich in organic carbon as topsoil, yet our analysis showed low concentrations of GDGTs (Table S1), confirming results from Peterse et al. (2014). Therefore, erosion of coastal ice complexes would affect the $\delta^{13} \mathrm{C}$ value of the sediments without significantly changing BIT values. Thus BIT may be measuring input from GDGT-rich fluvial sources, whilst $\delta^{13} \mathrm{C}$ integrates both fluvial influx and coastal erosion. An alternate explanation is that the brGDGTs responsible for the BIT index were degrading at a different rate compared to the bulk terrestrial organic carbon signal (Zhu et al., 2013). If brGDGTs, which made up a small proportion of the OC load of the sampled sediments (averaging $30 \mathrm{mg} \mathrm{g}_{\mathrm{OC}}{ }^{-1}$ ), degraded more rapidly than bulk organic matter, which may contain large amounts of resistant molecules such as lignin phenols or plant wax lipids (Feng et al., 2013; Tesi et al., 2014), then the two proxies were likely to have a non-linear relationship. However, Tesi et al. (2014) showed rapid offshore reduction in the concentration of lignin phenols and cutin acids among the same samples, which would suggest that the BIT results are not unique, and may be representing at least a portion of the bulk OC signal. This finding raises suspicion about the usefulness of the BIT index as a proxy for the proportion of terrestrial carbon in a bulk sediment sample where coastal erosion plays a large part, but introduces 

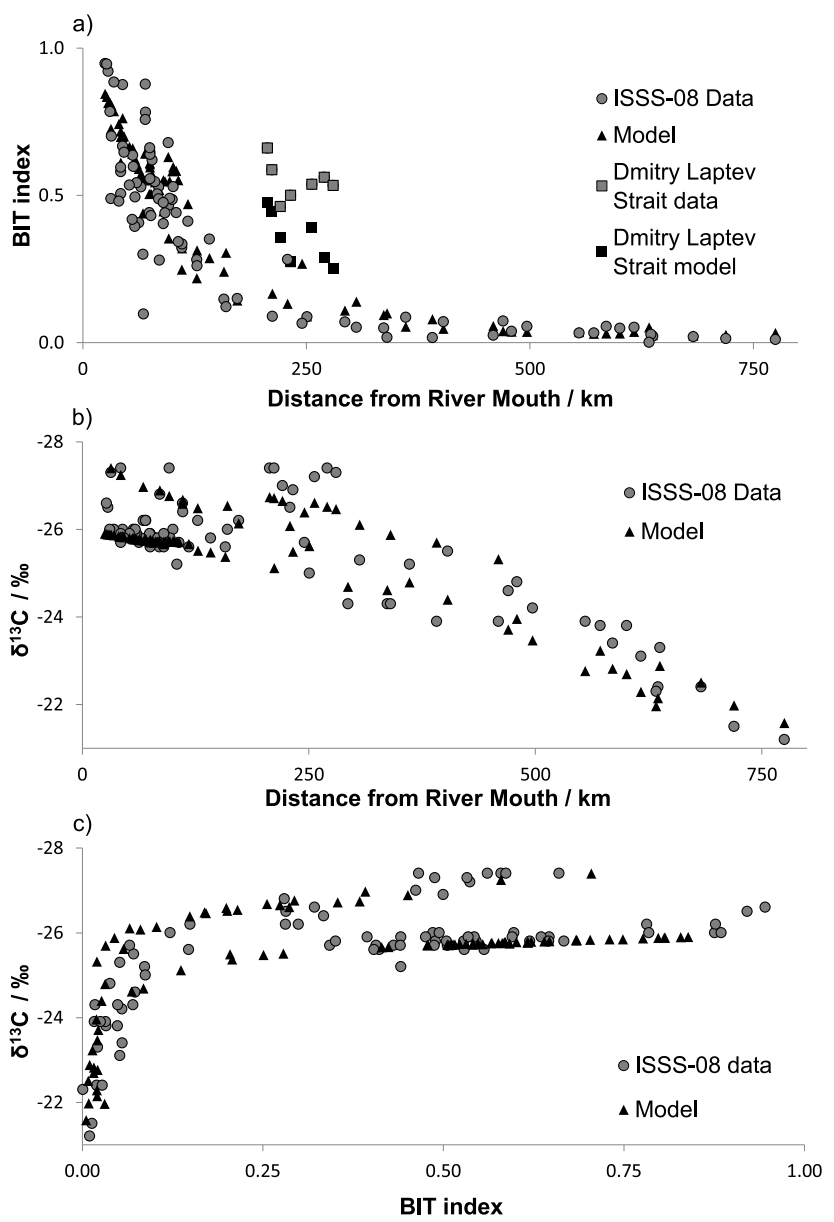

Figure 7. Comparison plots of sample parameters with modelled values. Grey symbols represent observed data from this study and Vonk et al. (2012); black symbols are modelled values. (a) BIT index vs. distance from river outflows. Samples from the DLS are shown separately, demonstrating how this region is offset from the general offshore-reduction trend in BIT, and showing the model recreating this trend. (b) $\delta^{13} \mathrm{C}$ vs. distance from river outflow. (c) $\delta^{13} \mathrm{C}$ vs. BIT index.

the possibility of its use as a more specific proxy for fluvial input.

\subsection{Modelling OC and GDGT delivery}

To investigate the sources and offshore behaviour of GDGTs and OC on the ESAS further, a simple model was created to simulate the deposition and degradation of terrestrial and marine material (Fig. S3). Apart from $\delta^{13} \mathrm{C}$, which has been shown to vary across the ESAS, single uniform values were applied across the entire ESAS rather than tuning the model to particular rivers or regions. A full description of the model is available in Appendix A.

Our data set, and other recent studies, has shown that fluvial systems in this region contain large amounts of brGDGTs and OC (De Jonge et al., 2014; Peterse et al.,
2014). Fluvial endmember values were defined using surface sediment samples closest to the great Russian Arctic river (GRAR) mouths. It is assumed that these samples represent an integrated signal from the river catchments, delivering mainly active layer soil material and, in the case of brGDGTs, in situ river production. We modelled fluvial delivery of sediment, OC and GDGTs from GRARs as a series of point sources, using the same sediment delivery conditions, from which material spread across the ESAS in a radial pattern. This leads to concentrations decreasing across the shelf in a $1 /$ distance pattern. The Siberian Arctic coastline experiences rapid coastal erosion, delivering large amounts of sediment and OC to the Arctic Ocean each year (Vonk et al., 2012). This process was modelled as a linear source of material stretching along the entire longitudinal range of this study, with a single value for OC and GDGT concentrations and sediment delivery rate. Endmember values were defined using ice complex samples, since these represent the majority of the sediment eroded from the East Siberian coastline (Schirrmeister et al., 2011). The OC, GDGTs and sediment delivered by coastal erosion decreased proportional to the distance from the coastline. Cren production peaked in the mid-latitude samples as discussed previously (Fig. 3b). This feature was reproduced simply in the model, with low marine OC and cren deposition close to the coastline and far offshore and a peak at $290 \mathrm{~km}$ offshore.

A degradation factor was applied to the model in order to simulate oxidation of organic matter in the water column. In the absence of more detailed studies, a simple rule was applied in which OC and biomarkers were degraded proportional to the distance travelled from source, and were assumed to have degraded completely by $800 \mathrm{~km}$ offshore. Initial conditions for sediment supply, OC concentration and $\delta^{13} \mathrm{C}$ for both fluvial and coastal erosion were defined using values from previous studies (Gordeev, 2006; Vonk et al., 2012). GDGT concentrations were defined using a single representative value based on samples from this study but were not "tuned" to specific regions, in order to avoid circularity (see Table S2 for model parameters). The model is based on simple principles and is applicable in other areas if the relevant endmember values (GDGT concentrations, $\delta^{13} \mathrm{C}$ ) and model parameters (e.g. fluvial/coastal sedimentary input rates) are known.

Through application of the uniform parameters described above as well as simple processes, the model reproduced measured offshore distributions of brGDGTs, cren, TOC, $\delta^{13} \mathrm{C}$ and BIT (Fig. 7). Transects from the river outflows were successfully reproduced, and the low-cren, high-BIT behaviour of the DLS was also qualitatively replicated. The model was then applied to the whole ESAS region included in this study in order to avoid sampling bias. In the model, rivers delivered $13 \%$ of the sediment to the ESAS but $72 \%$ of the brGDGTs, which supports the use of the BIT index as a proxy for fluvial rather than coastal sediment and terrOC delivery. As suggested by our measurements, brGDGTs 
are primarily delivered by rivers, which have eroded them from soils. There is the potential for in situ production within the river, but this cannot be quantified in this study. OC supply to the shelf was $40 \%$ fluvial, $44 \%$ coastal and $16 \%$ marine primary productivity. These findings are comparable to Vonk et al. (2012), although in their numerical model the role of coastal erosion was slightly greater (estimated $57 \%$ contribution from ice complexes). Using the degradation functions provided above, the model predicts that $23 \%$ of the exported terrOC was degraded between delivery and sampling. (This study only considers surface sediments, so the sampled material should at most be only a few years old. Subsequent diagenesis is ignored, but likely to be substantial; Arndt et al., 2013.) Using published sediment delivery estimates (Rachold et al., 2002; Gordeev, 2006) this degradation equates to $0.7 \mathrm{Tg} \mathrm{yr}^{-1}$ across the whole shelf, whilst $2.79 \mathrm{Tg} \mathrm{yr}^{-1}$ is deposited. Of this deposition, $1.13 \mathrm{Tg} \mathrm{yr}^{-1}$ comes from fluvial erosion, $1.23 \mathrm{Tg} \mathrm{yr}^{-1}$ from coastal erosion of ice complexes and $0.43 \mathrm{Tg} \mathrm{yr}^{-1}$ from burial of marine primary productivity. These figures are comparable to the values published by Semiletov et al. (2011), who found $4 \mathrm{Tg} \mathrm{yr}^{-1}$ of terrOC delivered to the Laptev and East Siberian seas, of which $0.38 \mathrm{Tg} \mathrm{yr}^{-1}$ was sourced from the Lena River. Vonk et al. (2012) produced higher estimates for terrOC delivery, $27 \mathrm{Tg} \mathrm{yr}^{-1}$ of which $7 \mathrm{Tg} \mathrm{yr}^{-1}$ is from fluvial sources and $20 \mathrm{Tg} \mathrm{yr}^{-1}$ from coastal erosion. These figures are higher than both our model and previous estimates due to the high sediment deposition rate measured on the ESAS by Vonk et al. (2012). Since their study suggests both a higher sedimentation rate and a proportionally greater influence of coastal erosion, further study of OC source and deposition rates is clearly needed in this complex environment.

\subsection{Use of brGDGTs as a tracer for river-derived sediment}

The patterns observed in the BIT and $\delta^{13} \mathrm{C}$ proxies, and the modelling results, support suggestions that the BIT index may be used not as a proxy for bulk soil export but for fluvial sediment delivery (De Jonge et al., 2014; Peterse et al., 2014). Observations of large-scale ice complex erosion and mobilisation in this area (Sánchez-García et al., 2014) are not carried forward into GDGT measurements, despite being identified in isotopic analyses (Vonk et al., 2012). Both the power-law reduction in BIT in an offshore direction and the non-linear relationship between BIT and $\delta^{13} \mathrm{C}$ can be explained by the interaction of three carbon pools. The model suggests that the majority of the brGDGTs are due to input of OC from rivers discharging to the East Siberian Sea, whilst BIT is less representative of coastal erosion. As a bulk proxy, $\delta^{13} \mathrm{C}$ is measuring the integrated effect of coastal erosion of terrestrial material, fluvial input and marine productivity, and therefore follows a different trend. Thus nearoutflow samples are river-dominated, nearshore samples are coastal-erosion-dominated and offshore samples are marine- enriched. The west-east decrease in BIT values (Fig. 2c), while it may be influenced by inflow of water through the Bering Strait, may also be explained by a fluvial signal, since the easternmost rivers are both smaller and will deliver lower amounts of brGDGTs during the spring freshet (Peterse et al., 2014).

\section{Conclusions}

In agreement with previous studies, GDGT analyses show that sediments on the ESAS are terrestrially dominated near to river outflows and in the Buor-Khaya Bay. The BIT index shows that there is a trend towards marine organic matter domination offshore. This transition is quite rapid, occurring within $150 \mathrm{~km}$ of the shoreline following a power-law distribution in all three regions of the Laptev and East Siberian seas. There is a non-linear relationship between the BIT index and $\delta^{13} \mathrm{C}$ measurements, which show a more gradual transition to marine compositions, indicating that offshore transport of material in this region is a complex process. The fluvial and coastal erosion patterns can be reproduced using a simple model that confirms suggestions that brGDGTs are primarily delivered by rivers. Fluvial delivery of brGDGTs and topsoil, coupled with coastal erosion of ice complex permafrost, can explain the patterns seen on the shelf and supports the use of brGDGTs as a proxy for fluvially delivered material in these sedimentary settings. 


\section{Appendix A: A model of offshore OC and GDGT delivery}

The model considers the export of GDGT biomarker molecules and organic carbon (OC) across the entire area of the ESAS included in this study. It is a simplified model in which a small number of processes and parameters are able to replicate the observed patterns across the ESAS. The model considers the delivery of sediment from both rivers and coastal erosion, and the organic carbon and GDGTs associated with this material. Combining this with marine primary productivity, we can model the delivery of sediment, terrestrial organic carbon and marine carbon to each position on the ESAS and calculate the BIT index and $\delta^{13} \mathrm{C}$ values that would be generated by that delivery.

Rivers are point sources of sediment, OC and biomarkers, distributed along the ESAS coastline. Measurements in this study showed that brGDGT concentrations were highest at the mouths of GRARs. From the river mouth, material was modelled as spreading out in a $1 /$ distance radial pattern, such that sediment, OC and GDGTs from fluvial sources were primarily deposited close to the river mouth, and concentrations dropped rapidly offshore. For simplicity, ocean currents were ignored, both surface and deep. Since GRAR outflow points are distributed 100s of $\mathrm{km}$ apart along the shoreline, the effects of interactions between river inputs was ignored - each position on the ESAS was modelled as only being affected by the closest river.

Measurements of the Kolyma River and associated lakes (Peterse et al., 2014), as well as the Yenisey River (De Jonge et al., 2014) and nearshore marine sediments from this study, showed that brGDGTs were abundant in fluvial sediment; this material is primarily sourced from soil erosion with minor contributions from in situ river production (Peterse et al., 2014). BIT values of 0.99 to 1 (Kolyma River, Peterse et al., 2014) and 0.95 to 1 (Yenisey River, De Jonge et al., 2014) showed that there was very little cren. OC and GDGT concentrations in fluvial material were parameterised using samples from this study collected closest to the river mouths. Single values for fluvial sediment output, OC and GDGT concentrations were applied to all rivers. $\delta^{13} \mathrm{C}$ values were set at $-28.1 \%$ in the Laptev Sea and $-26.3 \%$ in the ESS (Vonk et al., 2012).

Coastal erosion is a major source of sediment to the ESAS, and is prevalent along a majority of the East Siberian Arctic coastline (Rachold et al., 2002; Vonk et al., 2012). Coastal erosion mostly impacts ice complex material (Vonk et al., 2012), formed in a different manner when compared to permafrost soil. Considering the large differences between GDGT and other bacterial biomarker concentrations in these complexes when compared to the sediments collected near river mouths (Doğrul Selver et al., 2015), it is likely that these complexes support different microbial communities. This indicates that ice complexes are a major source of OC but not of brGDGTs. This is particularly seen in the con- centration of GDGTs measured in a range of ice complex samples, which was significantly lower than found in sediments collected near to river mouths. The delivery of sediment, OC and GDGTs from coastal erosion was modelled as a linear source, assuming that all sections of the coastline were acting as a source of material. This leads to sediment, OC and GDGT deposition rates decreasing proportional to the distance from source, in a linear fashion. OC and GDGT input from coastal erosion was parameterised from measurements in this study and published data (Gordeev, 2006; Vonk et al., 2012). Measurements from two vertical ice complex permafrost transects showed that GDGT concentrations were low throughout, so the coastal erosion sediment was a minor source of GDGTs to the ESAS. OC concentrations in the ice complex samples was similar to fluvial sediments. Coastally sourced sediment was given a $\delta^{13} \mathrm{C}$ signature matching the source area, $-27.1 \%$ in the Laptev Sea and $-26.0 \%$ in the ESS.

Degradation during transport is an important consideration for terrestrial OC and GDGTs; however it is currently very poorly understood and could only be parameterised as a simplified process. Since transport exposes OC and GDGTs to oxygenated water, degradation of both terrestrial OC and GDGTs was modelled as a function of the distance travelled from source. The model used a linear relationship between distance travelled and proportion degraded, such that by a given distance offshore (defined as $800 \mathrm{~km}$ ) all of the material was modelled as having been degraded. Obviously this is a simplification, since there are some recalcitrant fractions of OC that would certainly survive transport across the whole shelf - graphite particles have been observed far across the ESAS using the Raman spectroscopy technique of Sparkes et al. (2013) - but in the absence of a comprehensive degradation study in this region it is not possible to include a more thorough model. Specifically, it is not currently possible to model the individual degradation rates of multiple sources of OC such as soil-sourced versus river-produced GDGTs with any certainty.

In the model, marine primary productivity produces both marine OC and cren. Low-level production of brGDGTs in marine settings (Peterse et al., 2009) was treated as insignificant and ignored. Observations of cren distribution in the ESAS sediments (Fig. 3b), and of marine biomarkers in this region (Xiao et al., 2013), showed that productivity was maximum at intermediate distances across the shelf $\left(76-79^{\circ} \mathrm{N}\right)$, and reduced close to the shore and far offshore. These areas exhibit winter sea-ice cover for longer amounts of the year, which will reduce primary productivity, whilst the region between the polar ice cap and the terrestrially bound fast ice contains open-water polynyas (Xiao et al., 2013). A parabolic distribution was used to model the production of cren. This varied from $4.2 \mathrm{mg} \mathrm{m}^{-2} \mathrm{yr}^{-1}$ at $0 \mathrm{~km}$, to $17 \mathrm{mg} \mathrm{m}^{-2} \mathrm{yr}^{-1}$ at $290 \mathrm{~km}$, to zero productivity at $625 \mathrm{~km}$. However, there is very poor correlation between cren concentrations and $\delta^{13} \mathrm{C}$ across the shelf $\left(r^{2}=0.23\right.$; compare 
Figs. $3 \mathrm{~b}$ and $\mathrm{S} 2 \mathrm{~d}$ ). This suggests that there are marine sources of OC unrelated to the production of cren. In the absence of more precise data, marine OC production was modelled as a uniform $0.4 \mathrm{~g} \mathrm{~m}^{-2} \mathrm{yr}^{-1}$. These model parameters are collated in Table S2.

Each point on the ESAS was evaluated using GIS software that measured the distance to the closest river mouth and the closest coastline. These were given the values $D_{\text {riv }}$ and $D_{\text {coast }}$, respectively. This allowed the delivery of sediment, OC and GDGTs to be modelled for each location. Fluvial OC and GDGTs are a function of $1 / D_{\text {riv }}$. Ice complex OC and GDGTs are a function of $D_{\text {coast }}$, as are marine OC and cren. Having modelled the delivery of sediment, $\mathrm{OC}$ and GDGTs for each position on the shelf, TOC, $\delta^{13} \mathrm{C}$ and BIT values were calculated for comparison with measured data and application to the whole shelf carbon cycle. 


\section{The Supplement related to this article is available online at doi:10.5194/bg-12-3753-2015-supplement.}

Author contributions. Ö. Gustafsson, B. E. van Dongen, O. V. Dudarev, and I. P. Semiletov collected samples along with the crew of ISSS-08. B. E. van Dongen and H. M. Talbot designed the study, which was carried out by R. B. Sparkes and A. Doğrul Selver with assistance from J. Bischoff, and R. B. Sparkes designed and created the model. R. B. Sparkes prepared the manuscript with contributions from all co-authors.

Acknowledgements. We gratefully acknowledge receipt of a NERC research grant (NE/I024798/1 and NE/I027967/1) to B. E. van Dongen and H. M. Talbot, a $\mathrm{PhD}$ studentship to A. Doğrul Selver funded by the Ministry of National Education of Turkey, a research grant (p220/mega-grant 2013-220-04-157 \#14, Z50.31,0012/03.19.2014) from the government of the Russian Federation to I. P. Semiletov and O. V. Dudarev, and financial support as an academy research fellow to Ö. Gustafsson from the Swedish Royal Academy of Sciences through a grant from the Knut and Alice Wallenberg Foundation. We thank the crew and personnel of the R/V Yakob Smirnitskyi and all colleagues in the International Siberian Shelf Study (ISSS) programme for support, including sampling. We thank P. Lythgoe (University of Manchester) for invaluable assistance with LC-MS and T. Tesi for providing the ice complex samples for the Kolyma catchment area. The ISSS programme is supported by the Knut and Alice Wallenberg Foundation, the Far Eastern Branch of the Russian Academy of Sciences, the Swedish Research Council, the US National Oceanic and Atmospheric Administration, the Russian Foundation of Basic Research, the Swedish Polar Research Secretariat, the Nordic Council of Ministers and the US National Science Foundation. We thank one of the anonymous reviewers for their constructive comments, and another for their generous endorsement.

Edited by: S. Pantoja

\section{References}

Arndt, S., Jørgensen, B. B., LaRowe, D. E., Middelburg, J. J., Pancost, R. D., and Regnier, P.: Quantifying the degradation of organic matter in marine sediments: a review and synthesis, EarthSci. Rev., 123, 53-86, 2013.

Arrigo, K. R., van Dijken, G., and Pabi, S.: Impact of a shrinking Arctic ice cover on marine primary production, Geophys. Res. Lett., 35, L19603, doi:10.1029/2008GL035028, 2008.

Belicka, L. L. and Harvey, H. R.: The sequestration of terrestrial organic carbon in Arctic Ocean sediments: a comparison of methods and implications for regional carbon budgets, Geochim. Cosmochim. Ac., 73, 6231-6248, doi:10.1016/j.gca.2009.07.020, 2009.
Blaga, C., Reichart, G.-J., Heiri, O., and Sinninghe Damsté, J. S.: Tetraether membrane lipid distributions in water-column particulate matter and sediments: a study of 47 European lakes along a north-south transect, J. Paleolimnol., 41, 523-540, 2009.

Cooke, M. P., Talbot, H. M., and Wagner, T.: Tracking soil organic carbon transport to continental margin sediments using soil-specific hopanoid biomarkers: a case study from the Congo fan (ODP site 1075), Org. Geochem., 39, 965-971, doi:10.1016/j.orggeochem.2008.03.009, 2008.

Cremer, H.: Distribution patterns of diatom surface sediment assemblages in the Laptev Sea (Arctic Ocean), Mar. Micropaleontol., 38, 39-67, 1999.

De Jonge, C., Stadnitskaia, A., Hopmans, E. C., Cherkashov, G., Fedotov, A., and Sinninghe Damsté, J. S.: In situ produced branched glycerol dialkyl glycerol tetraethers in suspended particulate matter from the Yenisei River, Eastern Siberia, Geochim. Cosmochim. Ac., 125, 476-491, 2014.

Doğrul Selver, A., Talbot, H. M., Gustafsson, O., Boult, S., and van Dongen, B. E.: Soil organic matter transport along an sub-Arctic river-sea transect, Org. Geochem., 51, 63-72, 2012.

Doğrul Selver, A., Sparkes, R. B., Bischoff, J., Talbot, H. M., Gustafsson, O., Semiletov, I. P., Dudarev, O. V., Boult, S., and van Dongen, B. E.: Distributions of bacterial and archaeal membrane lipids in surface sediments along the Kolyma Palaeoriver transect, East Siberian Sea, Org. Geochem., 83-84, 16-26, 2015.

Drenzek, N. J., Montluçon, D. B., Yunker, M. B., Macdonald, R. W., and Eglinton, T. I.: Constraints on the origin of sedimentary organic carbon in the Beaufort Sea from coupled molecular 13C and 14C measurements, Mar. Chem., 103, 146-162, doi:10.1016/j.marchem.2006.06.017, 2007.

Feng, X., Vonk, J. E., van Dongen, B. E., Gustafsson, O., Semiletov, I. P., Dudarev, O. V., Wang, Z., Montluçon, D. B., Wacker, L., and Eglinton, T. I.: Differential mobilization of terrestrial carbon pools in Eurasian Arctic river basins, P. Natl. Acad. Sci. USA 110, 35, 14168-14173, doi:10.1073/pnas.1307031110, 2013.

Galy, V., France-Lanord, C., Beyssac, O., Faure, P., Kudrass, H., and Palhol, F.: Efficient organic carbon burial in the Bengal fan sustained by the Himalayan erosional system, Nature, 450, $407-$ 410, 2007.

Goñi, M. A., Yunker, M. B., Macdonald, R. W., and Eglinton, T. I.: The supply and preservation of ancient and modern components of organic carbon in the Canadian Beaufort Shelf of the Arctic Ocean, Mar. Chem., 93, 53-73, doi:10.1016/j.marchem.2004.08.001, 2005.

Gordeev, V. V.: Fluvial sediment flux to the Arctic Ocean, Geomorphology, 80, 94-104, 2006.

Guo, L., Semiletov, I., Gustafsson, O., Ingri, J., Andersson, P., Dudarev, O., and White, D.: Characterization of Siberian Arctic coastal sediments: implications for terrestrial organic carbon export, Global Biogeochem. Cy., 18, GB1036, doi:10.1029/2003GB002087, 2004.

Gustafsson, Ö., van Dongen, B. E., Vonk, J. E., Dudarev, O. V., and Semiletov, I. P.: Widespread release of old carbon across the Siberian Arctic echoed by its large rivers, Biogeosciences, 8, 1737-1743, doi:10.5194/bg-8-1737-2011, 2011.

Hedges, J. I., Keil, R. G., and Benner, R.: What happens to terrestrial organic matter in the ocean?, Org. Geochem., 27, 195-212, doi:10.1016/S0146-6380(97)00066-1, 1997. 
Heim, B., Abramova, E., Doerffer, R., Günther, F., Hölemann, J., Kraberg, A., Lantuit, H., Loginova, A., Martynov, F., Overduin, P. P., and Wegner, C.: Ocean colour remote sensing in the southern Laptev Sea: evaluation and applications, Biogeosciences, 11, 4191-4210, doi:10.5194/bg-11-4191-2014, 2014.

Ho, S. L., Mollenhauer, G., Fietz, S., Martínez-Garcia, A., Lamy, F., Rueda, G., Schipper, K., Méheust, M., Rosell-Melé, A., Stein, R., and Tiedemann, R.: Appraisal of TEX86 and and TEXL86 thermometries in subpolar and polar regions, Geochim. Cosmochim. Ac., 131, 213-226, 2014.

Hopmans, E. C., Weijers, J. W. H., Schefuß, E., Herfort, L., Sinninghe Damsté, J. S., and Schouten, S.: A novel proxy for terrestrial organic matter in sediments based on branched and isoprenoid tetraether lipids, Earth Planet. Sc. Lett., 224, 107-116, doi:10.1016/j.epsl.2004.05.012, 2004.

IPCC: Climate Change 2013: The Physical Science Basis, Contribution of Working Group I to the Fifth Assessment Report of the Intergovernmental Panel on Climate Change, Tech. rep., 362366,2013

Kao, S.-J., Hilton, R. G., Selvaraj, K., Dai, M., Zehetner, F., Huang, J.-C., Hsu, S.-C., Sparkes, R., Liu, J. T., Lee, T.-Y., Yang, J.-Y. T., Galy, A., Xu, X., and Hovius, N.: Preservation of terrestrial organic carbon in marine sediments offshore Taiwan: mountain building and atmospheric carbon dioxide sequestration, Earth Surf. Dynam., 2, 127-139, doi:10.5194/esurf-2-127-2014, 2014.

Karlsson, E. S., Charkin, A., Dudarev, O., Semiletov, I., Vonk, J. E., Sánchez-García, L., Andersson, A., and Gustafsson, Ö.: Carbon isotopes and lipid biomarker investigation of sources, transport and degradation of terrestrial organic matter in the Buor-Khaya Bay, SE Laptev Sea, Biogeosciences, 8, 1865-1879, doi:10.5194/bg-8-1865-2011, 2011.

Kienast, F., Schirrmeister, L., Siegert, C., and Tarasov, P.: Palaeobotanical evidence for warm summers in the East Siberian Arctic during the last cold stage, Quaternary Res., 63, 283-300, 2005.

Kim, J.-H., Schouten, S., Buscail, R., Ludwig, W., Bonnin, J., Sinninghe Damsté, J. S., and Bourrin, F.: Origin and distribution of terrestrial organic matter in the NW Mediterranean (Gulf of Lions): exploring the newly developed BIT index, Geochem. Geophy. Geosy., 7, 11, Q11017, doi:10.1029/2006GC001306, 2006.

Kim, J.-H., Buscail, R., Fanget, A.-S., Eyrolle-Boyer, F., Bassetti, M.-A., Dorhout, D., Baas, M., Berné, S., and Damsté, J. S. S.: Impact of river channel shifts on tetraether lipids in the Rhône prodelta (NW Mediterranean): implication for the $\{$ BIT $\}$ index as an indicator of palaeoflood events, Org. Geochem., 75, 99-108, doi:10.1016/j.orggeochem.2014.06.011, 2014.

Kotlyakov, V. and Khromova, T.: Maps of permafrost and ground ice, in: Land Resources of Russia, National Snow and Ice Data Center, Boulder, available at: http://nsidc.org/api/metadata?id= ggd600 (last access: 12 June 2015), 2002.

McClymont, E. L., Ganeshram, R. S. S., Pichevin, L. E., Talbot, H., van Dongen, B., Thunell, R. C., Haywood, A. M., Singarayer, J. S., and Valdes, P. J.: Sea-surface temperature records of termination 1 in the Gulf of California: challenges for seasonal and inter-annual analogues of tropical Pacific climate change, $\mathrm{Pa}-$ leoceanography, 27, PA2202, doi:10.1029/2011PA02226, 2012.

Peterse, F., Kim, J.-H., Schouten, S., Kristensen, D. K., Koç, N., and Sinninghe Damsté, J. S.: Constraints on the application of the MBT/CBT palaeothermometer at high latitude envi- ronments (Svalbard, Norway), Org. Geochem., 40, 692-699, doi:10.1016/j.orggeochem.2009.03.004, 2009.

Peterse, F., Vonk, J. E., Holmes, R. M., Giosan, L., Zimov, N., and Eglinton, T. I.: Branched glycerol dialkyl glycerol tetraethers in Arctic lake sediments: sources and implications for paleothermometry at high latitudes, J. Geophys. Res.-Biogeo., 119, 17391754, doi:10.1002/2014JG002639, 2014.

Peterson, B. J., Holmes, R. M., McClelland, J. W., Vörösmarty, C. J., Lammers, R. B., Shiklomanov, A. I., Shiklomanov, I. A., and Rahmstorf, S.: Increasing river discharge to the Arctic Ocean, Science, 298, 2171-2173, doi:10.1126/science.1077445, 2002.

Rachold, V., Grigoriev, M. N., and Bauch, H. A.: An estimation of the sediment budget in the Laptev Sea during the last 5000 years, Polarforschung, 70, 151-157, 2002.

Sakshaug, E. and Slagstad, D.: Sea ice and wind: effects on primary productivity in the Barents Sea, Atmos. Ocean, 30, 579591, doi:10.1080/07055900.1992.9649456, 1992.

Sánchez-García, L., Vonk, J. E., Charkin, A. N., Kosmach, D., Dudarev, O. V., Semiletov, I. P., and Gustafsson, O.: Characterisation of three regimes of collapsing Arctic ice complex deposits on the SE Laptev Sea coast using biomarkers and dual carbon isotopes, Permafrost Periglac., 25, 172-183, doi:10.1002/ppp.1815, 2014.

Savelieva, N., Semiletov, I., Vasilevskaya, L., and Pugach, S.: A climate shift in seasonal values of meteorological and hydrological parameters for Northeastern Asia, Prog. Oceanogr., 47, 279-297, doi:10.1016/S0079-6611(00)00039-2, 2000.

Schirrmeister L., Kunitsky V., Grosse G., Wetterich S., Meyer H., Schwamborn G., Babiy O., Derevyagin A., and Siegert C.: Sedimentary characteristics and origin of the Late Pleistocene Ice Complex on north-east Siberian Arctic coastal lowlands and islands - A review, Quaternary International, 241, 3-25, doi:10.1016/j.quaint.2010.04.004, 2011.

Schouten, S., Hopmans, E. C., Rosell-Melé, A., Pearson, A., Adam, P., Bauersachs, T., Bard, E., Bernasconi, S. M., Bianchi, T. S., Brocks, J. J., Carlson, L. T., Castañeda, I. S., Derenne, S., Doğrul Selver, A., Dutta, K., Eglinton, T., Fosse, C., Galy, V., Grice, K., Hinrichs, K.-U., Huang, Y., Huguet, A., Huguet, C., Hurley, S., Ingalls, A., Jia, G., Keely, B., Knappy, C., Kondo, M., Krishnan, S., Lincoln, S., Lipp, J., Mangelsdorf, K., Martínez-García, A., Ménot, G., Mets, A., Mollenhauer, G., Ohkouchi, N., Ossebaar, J., Pagani, M., Pancost, R. D., Pearson, E. J., Peterse, F., Reichart, G.-J., Schaeffer, P., Schmitt, G., Schwark, L., Shah, S. R., Smith, R. W., Smittenberg, R. H., Summons, R. E., Takano, Y., Talbot, H. M., Taylor, K. W. R., Tarozo, R., Uchida, M., van Dongen, B. E., Van Mooy, B. A. S., Wang, J., Warren, C., Weijers, J. W. H., Werne, J. P., Woltering, M., Xie, S., Yamamoto, M., Yang, H., Zhang, C. L., Zhang, Y., Zhao, M., and Sinninghe Damsté, J. S.: An interlaboratory study of TEX86 and BIT analysis of sediments, extracts, and standard mixtures, Geochem. Geophy. Geosy., 14, 52635285, 2013.

Semiletov, I. P.: The failure of the coastal permafrost as an important factor in biogeochemistry of the Arctic shelf waters, transactions of Russia Academy of Sciences [Doklady], 369, 11401143, 1999a. 
Semiletov, I. P.: Aquatic Sources and Sinks of $\mathrm{CO}_{2}$ and $\mathrm{CH}_{4}$ in the Polar Regions, J. Atmos. Sci., 56, 286-306, doi:10.1175/15200469(1999)056<0286:ASASOC>2.0.CO;2, $1999 \mathrm{~b}$.

Semiletov, I. and Gustafsson, O.: East Siberian shelf study alleviates scarcity of observations, eos, Transactions American Geophysical Union, 90, 145-146, 2009.

Semiletov, I., Savelieva, N., Weller, G., Pipko, I., Pugach, S., Gukov, A., and Vasilevskaya, L.: The dispersion of Siberian river flows into coastal waters: meteorological, hydrological and hydrochemical aspects, in: The Freshwater Budget of the Arctic Ocean, edited by: Lewis, E., Jones, E., Lemke, P., Prowse, T., and Wadhams, P., vol. 70 of NATO Science Series, Springer, the Netherlands, doi:10.1007/978-94-011-4132-1_15, 323-366, 2000 .

Semiletov, I., Dudarev, O., Luchin, V., Charkin, A., Shin, K.-H., and Tanaka, N.: The East Siberian Sea as a transition zone between Pacific-derived waters and Arctic shelf waters, Geophys. Res. Lett., 32, L10614, doi:10.1029/2005GL022490, 2005.

Semiletov, I. P., Pipko, I. I., Repina, I., and Shakhova, N. E.: Carbonate chemistry dynamics and carbon dioxide fluxes across the atmosphere-ice-water interfaces in the Arctic Ocean: Pacific sector of the Arctic, J. Marine Syst., 66, 204-226, 2007.

Semiletov, I. P., Pipko, I. I., Shakhova, N. E., Dudarev, O. V., Pugach, S. P., Charkin, A. N., McRoy, C. P., Kosmach, D., and Gustafsson, Ö.: Carbon transport by the Lena River from its headwaters to the Arctic Ocean, with emphasis on fluvial input of terrestrial particulate organic carbon vs. carbon transport by coastal erosion, Biogeosciences, 8, 2407-2426, doi:10.5194/bg8-2407-2011, 2011.

Semiletov, I. P., Shakhova, N. E., Sergienko, V. I., Pipko, I. I., and Dudarev, O. V.: On carbon transport and fate in the East Siberian Arctic land-shelf-atmosphere system, Environ. Res. Lett., 7, 015201, doi:10.1088/1748-9326/7/1/015201, 2012.

Semiletov, I. P., Shakhova, N. E., Pipko, I. I., Pugach, S. P., Charkin, A. N., Dudarev, O. V., Kosmach, D. A., and Nishino, S.: Spacetime dynamics of carbon and environmental parameters related to carbon dioxide emissions in the Buor-Khaya Bay and adjacent part of the Laptev Sea, Biogeosciences, 10, 5977-5996, doi:10.5194/bg-10-5977-2013, 2013.

Shakhova, N. and Semiletov, I.: Methane release and coastal environment in the East Siberian Arctic shelf, J. Marine Syst., 66, 227-243, doi:10.1016/j.jmarsys.2006.06.006, 5th International Symposium on Gas Transfer at Water Surfaces Selected papers from the 37th International Liege Colloquium on Ocean Dynamics 37th International Liege Colloquium on Ocean Dynamics, 2007.

Shakhova, N. E., Sergienko, V., and Semiletov, I. P.: The contribution of the East Siberian shelf to the modern methane cycle, Her. Russ. Acad. Sci.t, 79, 237-246, doi:10.1134/S101933160903006X, 2009.

Shakhova, N., Semiletov, I., Leifer, I., Salyuk, A., Rekant, P., and Kosmach, D.: Geochemical and geophysical evidence of methane release over the East Siberian Arctic Shelf, J. Geophys. Res.-Oceans, 115, C08007, doi:10.1029/2009JC005602, 2010a.

Shakhova, N., Semiletov, I., Salyuk, A., Yusupov, V., Kosmach, D., and Gustafsson, O.: Extensive methane venting to the atmosphere from sediments of the East Siberian Arctic Shelf, Science, 327, 1246-1250, 2010b.
Shakhova, N., Semiletov, I., Leifer, I., Sergienko, V., Salyuk, A., Kosmach, D., Chernykh, D., Stubbs, C., Nicolsky, D., Tumskoy, V., and Gustafsson, O.: Ebullition and storm-induced methane release from the East Siberian Arctic Shelf, Nature Geosci., 7, 64-70, doi:10.1038/ngeo2007, 2014.

Sinninghe Damsté, J. S., Schouten, S., Hopmans, E. C., Van Duin, C. T., and Geenevasen, J. A. J.: Crenarchaeol: the characteristic core glycerol dibiphytanyl glycerol tetraether membrane lipid of cosmopolitan pelagic crenarchaeota, J. Lipid Res., 43, 1641-1651, 2002.

Sistla, S. A., Moore, J. C., Simpson, R. T., Gough, L., Shaver, G. R., and Schimel, J. P.: Long-term warming restructures Arctic tundra without changing net soil carbon storage, Nature, 497, 615-618, 2013.

Smith, R. W., Bianchi, T. S., and Li, X.: A re-evaluation of the use of branched GDGTs as terrestrial biomarkers: implications for the BIT Index, Geochim. Cosmochim. Ac., 80, 14-29, doi:10.1016/j.gca.2011.11.025, 2012.

Soloviev, V. A., Ginzburg, G. D., Telepnev, E. V., and Mikhaluk, Y. N.: Cryothermia and Gas Hydrates in the Arctic Ocean (VNIIOkeangeolia), 1987.

Sparkes, R., Hovius, N., Galy, A., Kumar, R. V., and Liu, J. T.: Automated analysis of carbon in powdered geological and environmental samples by Raman spectroscopy, Appl. Spectrosc., 67, 779-788, http://as.osa.org/abstract.cfm?URI=as-67-7-779, 2013.

Tarnocai, C., Canadell, J. G., Schuur, E. A. G., Kuhry, P., Mazhitova, G., and Zimov, S.: Soil organic carbon pools in the northern circumpolar permafrost region, Global Biogeochem. Cy., 23, GB2023, doi:10.1029/2008GB003327, 2009.

Tesi, T., Semiletov, I., Hugelius, G., Dudarev, O., Kuhry, P., and Gustafsson, O.: Composition and fate of terrigenous organic matter along the Arctic land-ocean continuum in East Siberia: insights from biomarkers and carbon isotopes, Geochim. Cosmochim. Ac., 133, 235-256, doi:10.1016/j.gca.2014.02.045 2014.

Tierney, J. E., Schouten, S., Pitcher, A., Hopmans, E. C., and Sinninghe Damsté, J. S.: Core and intact polar glycerol dialkyl glycerol tetraethers (GDGTs) in Sand Pond, Warwick, Rhode Island (USA): insights into the origin of lacustrine GDGTs, Geochim. Cosmochim. Ac., 77, 561-581, doi:10.1016/j.gca.2011.10.018, 2012.

van Dongen, B. E., Semiletov, I., Weijers, J. W. H., and Gustafsson, O.: Contrasting lipid biomarker composition of terrestrial organic matter exported from across the Eurasian Arctic by the five great Russian Arctic rivers, Global Biogeochem. Cy., 22, GB1011, doi:10.1029/2007GB002974, 2008.

van Everdingen, R.: Multi-language glossary of permafrost and related ground-ice terms, Tech. rep., National Snow and Ice Data Center, Boulder CO, available at: http://nsidc.org/fgdc/glossary/ (last access: 12 June 2015), 1998.

Vonk, J. E., van Dongen, B. E., and Gustafsson, O.: Selective preservation of old organic carbon fluvially released from sub-Arctic soils, Geophys. Res. Lett., 37, L11605, doi:10.1029/2010g1042909, 2010.

Vonk, J. E., Sanchez-Garcia, L., van Dongen, B. E., Alling, V., Kosmach, D., Charkin, A., Semiletov, I. P., Dudarev, O. V., Shakhova, N., Roos, P., Eglinton, T. I., Andersson, A., and Gustafsson, O.: Activation of old carbon by erosion of coastal 
and subsea permafrost in Arctic Siberia, Nature, 489, 137-140, doi:10.1038/nature11392, 2012.

Weijers, J. W. H., Schouten, S., Spaargaren, O. C., and Sinninghe Damsté, J. S.: Occurrence and distribution of tetraether membrane lipids in soils: implications for the use of the TEX86 proxy and the BIT index, Org. Geochem., 37, 1680-1693, doi:10.1016/j.orggeochem.2006.07.018, 2006.

Weijers, J. W. H., Schouten, S., van den Donker, J. C., Hopmans, E. C., and Sinninghe Damsté, J. S.: Environmental controls on bacterial tetraether membrane lipid distribution in soils, Geochim. Cosmochim. Ac., 71, 703-713, doi:10.1016/j.gca.2006.10.003, 2007.

Weijers, J. W. H., Bernhardt, B., Peterse, F., Werne, J. P., Dungait, J. A. J., Schouten, S., and Sinninghe Damsté, J. S.: Absence of seasonal patterns in MBT-CBT indices in midlatitude soils, Geochim. Cosmochim. Ac., 75, 3179-3190, doi:10.1016/j.gca.2011.03.015, 2011.

Xiao, X., Fahl, K., and Stein, R.: Biomarker distributions in surface sediments from the Kara and Laptev seas (Arctic Ocean): indicators for organic-carbon sources and sea-ice coverage, Quaternary Sci. Rev., 79, 40-52, 2013.
Zell, C., Kim, J.-H., Abril, G., Sobrinho, R., Dorhout, D., MoreiraTurcq, P., and Sinninghe Damsté, J.: Impact of seasonal hydrological variation on the distributions of tetraether lipids along the Amazon River in the central Amazon basin: implications for the MBT/CBT paleothermometer and the BIT index, Frontiers in Microbiology, 4, 228, doi:10.3389/fmicb.2013.00228, 2013.

Zhu, C., Talbot, H. M., Wagner, T., Pan, J.-M., and Pancost, R. D.: Distribution of hopanoids along a land to sea transect: implications for microbial ecology and the use of hopanoids in environmental studies Journal Limnol. Oceanogr., Limnol. Oceanogr., 56, 1850-1865, doi:10.4319/lo.2011.56.5.1850, 2011.

Zhu, C., Wagner, T., Talbot, H. M., Weijers, J. W. H., Pan, J.-M., and Pancost, R. D.: Mechanistic controls on diverse fates of terrestrial organic components in the East China Sea, Geochim. Cosmochim. Ac., 117, 129-143, 2013.

Zimov, S. A., Schuur, E. A. G., and Chapin, F. S.: Permafrost and the Global Carbon Budget, Science, 312, 1612-1613, doi:10.1126/science.1128908, 2006. 